\title{
Construction Technology of Recycled Micro-surfacing of Yong wu Highway
}

\author{
He Jiang \\ Highway Institute of Chang'an University, Xi an, Shanxi, China 710064 \\ 610981300@qq.com
}

\begin{abstract}
Keywords: highway engineering preventive maintenance recycled Micro-surfacing Recycled Asphalt Mixture.

Abstract. This paper introduces design of mix proportion of recycled Micro-surfacing technology mixing with a certain amount of Recycled Asphalt Mixture (referred to as the RAP) and its application in preventive maintenance for Yunnan Yong wu highway.
\end{abstract}

\section{Introduction}

Recycling Micro-surfacing is a preventive maintenance technology using Recycled Asphalt Mixture to replace new aggregates on the base of Micro-surfacing.

Compared with the mixture design of Micro-surfacing, the design of Recycled Micro-surfacing mainly increases the evaluation and test of Recycled Asphalt Mixture 、 determining the blending ratio of Recycled Asphalt Mixture and new aggregate by chosing the type of modified asphalt emulsion 、 estimating the amount of new asphalt 、 determining optimum asphalt content 、 making comprehensive evaluation of construction and pavement performance [1].

Yongren-Wuding Expressway is an important section of the country's western development channel of Lanzhou-Mohan highway in Yunnan Province. After the operation of nearly seven years, slight ruts and longitudinal cracks appear, which greatly affect its safety and comfort. The preventive maintenance scheme of recycled micro-surfacing of MS-3 was chosen to solve this problem.

\section{Raw material selection}

Mineral aggregate. Recycled Asphalt Mixture (RAP) mainly comes from pavement surface course and the milling velocity should be controlled between 4 to 8 meters per minute. After screened the RAP by using crushing and screening equipment, the size of 0 to $9.5 \mathrm{~mm}$ can be used.

Modified asphalt emulsion. The complex formulations of modified asphalt emulsion by using MWV emulsifier MQ3 (0.7\%) add emulsifier MQ65 (0.8\%). The modifier is SBR latex (solids content $60 \%$ ), and the content in emulsified asphalt is $3 \%$. the test of residue bitumen content is as follows: the content $65.4 \%$, ductility $24.0 \mathrm{~cm}$, penetration $55.3(0.01 \mathrm{~mm})$, softening point $66.0{ }^{\circ} \mathrm{C}$.

\section{The gradation design of recycled micro-surfacing mixture}

The addition ratio of RAP initially selected was 30\%, the gradation as follows: RAP (0-10mm): basalt $(5-10 \mathrm{~mm})$ : basalt $(3-5 \mathrm{~mm})$ : limestone $(0-3 \mathrm{~mm})=30 \%: 10 \%: 0 \%: 60 \%$.

Cohesion torque test. The initial setting time and opening traffic time of recycled micro-surfacing mixture is primarily evaluated by cohesion torque test, which has a significant impact on whether the micro-surfacing can meet the requirements of opening traffic earlier. The results of cohesion torque test are show in Table 1. 
Table 1 Cohesion torque test

\begin{tabular}{|c|c|c|c|c|c|}
\hline $\begin{array}{l}\text { The amount } \\
\text { of modified } \\
\text { asphalt } \\
\text { emulsion } \\
(\%)\end{array}$ & $\begin{array}{l}\text { The amount } \\
\text { of water }(\%)\end{array}$ & $\begin{array}{l}\text { The } \\
\text { amount of } \\
\text { cement } \\
(\%)\end{array}$ & $\begin{array}{l}\text { Cohesion } \\
\text { torque after } \\
\text { 30min }\end{array}$ & $\begin{array}{l}\text { Cohesion torque } \\
\text { after } 60 \mathrm{~min}\end{array}$ & remark \\
\hline 9 & 8 & 1.5 & $1.53(45 \mathrm{~min})$ & $\begin{array}{c}1.71 \\
(\text { some loose } \\
\text { particles in surface) }\end{array}$ & \\
\hline 9.5 & 8 & 1.5 & $1.35(35 \mathrm{~min})$ & $\begin{array}{c}1.63 \\
\text { (some loose } \\
\text { particles in surface) }\end{array}$ & $\begin{array}{l}\text { Specimens } \\
\text { after } \\
\text { molding }\end{array}$ \\
\hline 10 & 8 & 1.5 & 1.44 & $\begin{array}{c}1.51 \\
\text { (some cracks in } \\
\text { surface) }\end{array}$ & $\begin{array}{l}\text { drying in } \\
\text { the sun } \\
\text { indoors }\end{array}$ \\
\hline 10.5 & 8 & 1.5 & 1.47 & $\begin{array}{c}1.57 \\
\text { (some cracks in } \\
\text { surface })\end{array}$ & \\
\hline
\end{tabular}

NOTE: Too much water leads strength increasing slowly after 30min, but from the appearance of the specimen, the cohesion torque is better when the amount of modified asphalt emulsion is less than $9.0 \%$.

Wet track abrasion test. the optimum amount of modified asphalt emulsion in micro-surfacing mixture is determined by wet track abrasion test and load wheel test. The results of wet track abrasion test are shown in Table 2.

Table 2 Wet track abrasion test (Wear area of rubber tube is $0.035 \mathrm{~m}^{2}$ )

\begin{tabular}{|c|c|c|c|c|c|c|}
\hline $\begin{array}{l}\text { The amount of } \\
\text { modified } \\
\text { asphalt } \\
\text { emulsion }(\%)\end{array}$ & $\begin{array}{c}\text { The amount of } \\
\text { water }(\%)\end{array}$ & $\begin{array}{l}\text { The } \\
\text { amount } \\
\text { of } \\
\text { cement } \\
(\%)\end{array}$ & $\mathrm{m}_{\mathrm{a}}$ & $\mathrm{m}_{\mathrm{b}}$ & $\begin{array}{c}\text { The abrasion } \\
\text { value after } \\
\text { soaking in water } \\
\text { for } 1 \text { hour }\left(\mathrm{g} / \mathrm{m}^{2}\right)\end{array}$ & Means \\
\hline \multirow{3}{*}{8} & \multirow{4}{*}{8} & \multirow{3}{*}{1.5} & 1009.52 & 993.38 & 461.14 & \multirow{3}{*}{448.0} \\
\hline & & & 998.48 & 983.17 & 437.43 & \\
\hline & & & 1019.13 & 1003.54 & 445.43 & \\
\hline \multirow{3}{*}{8.5} & & \multirow{3}{*}{1.5} & 1036.64 & 1023.15 & 385.43 & \multirow{3}{*}{405.2} \\
\hline & \multirow[t]{2}{*}{8} & & 1028.31 & 1013.54 & 422.00 & \\
\hline & & & 1029.85 & 1015.56 & 408.29 & \\
\hline \multirow{3}{*}{9} & \multirow{3}{*}{9} & \multirow{3}{*}{1.5} & 997.10 & 986.22 & 310.86 & \multirow{3}{*}{305.8} \\
\hline & & & 1018.99 & 1008.32 & 304.86 & \\
\hline & & & 1038.00 & 1027.44 & 301.71 & \\
\hline \multirow{3}{*}{9.5} & \multirow{3}{*}{9} & \multirow{3}{*}{1.5} & 1031.35 & 1027.55 & 108.57 & \multirow{3}{*}{129.8} \\
\hline & & & 1032.51 & 1027.50 & 143.14 & \\
\hline & & & 1053.82 & 1049.00 & 137.71 & \\
\hline \multirow{3}{*}{10} & \multirow{3}{*}{9} & \multirow{3}{*}{1.5} & 1059.91 & 1056.52 & 96.86 & \multirow{3}{*}{105.2} \\
\hline & & & 1033.19 & 1029.58 & 103.14 & \\
\hline & & & 1053.18 & 1049.13 & 115.71 & \\
\hline
\end{tabular}

From Table 2, with the increase in the amount of modified asphalt emulsion, the abrasion value after soaking in water for 1 hour decreases, but according to the specification [2], abrasion value should not be greater than $540 \mathrm{~g} / \mathrm{m}^{2}$, the law is clearly visible. When the amount of modified asphalt emulsion is $8.0 \%-8.5 \%$, all the abrasion values meet the requirements, so that the amount of modified asphalt emulsion can be reduced in micro-surfacing mixture. 
Load wheel test. The results of load wheel test are shown in Table 3.

Table 3 Load wheel test (Rolling area of rubber wheels is $0.0081 \mathrm{~m}^{2}$ )

\begin{tabular}{|c|c|c|c|c|c|c|}
\hline $\begin{array}{l}\text { The amount } \\
\text { of modified } \\
\text { asphalt } \\
\text { emulsion }(\%)\end{array}$ & $\begin{array}{c}\text { The } \\
\text { amount of } \\
\text { water }(\%)\end{array}$ & $\begin{array}{c}\text { The amount } \\
\text { of cement } \\
(\%)\end{array}$ & G1 & $\mathrm{G} 2$ & $\begin{array}{l}\text { The amount } \\
\text { of sticky sand } \\
\quad(\mathrm{g} / \mathrm{m} 2)\end{array}$ & Means \\
\hline \multirow[t]{4}{*}{ 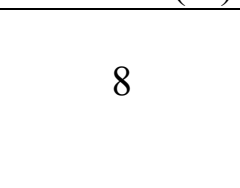 } & \multirow{4}{*}{8} & \multirow{3}{*}{1.5} & 542.17 & 545.26 & 381.48 & \multirow{3}{*}{393.83} \\
\hline & & & 536.26 & 540.71 & 549.38 & \\
\hline & & & 534.36 & 536.39 & 250.62 & \\
\hline & & \multirow{3}{*}{1.5} & 561.69 & 565.8 & 507.41 & \multirow{3}{*}{459.67} \\
\hline \multirow[t]{3}{*}{8.5} & \multirow[t]{3}{*}{8} & & 529.62 & 532.5 & 355.56 & \\
\hline & & & 551.36 & 555.54 & 516.05 & \\
\hline & & \multirow{3}{*}{1.5} & 575.14 & 580.66 & 681.48 & \multirow{3}{*}{649.79} \\
\hline \multirow[t]{3}{*}{9} & \multirow[t]{3}{*}{8} & & 598.15 & 602.84 & 579.01 & \\
\hline & & & 602.12 & 607.7 & 688.89 & \\
\hline & & \multirow{3}{*}{1.5} & 574.93 & 580.48 & 685.19 & \multirow{3}{*}{741.15} \\
\hline \multirow[t]{2}{*}{9.5} & \multirow[t]{3}{*}{8} & & 582.45 & 587.52 & 625.93 & \\
\hline & & & 589.41 & 596.8 & 912.35 & \\
\hline \multirow{3}{*}{10} & & \multirow{3}{*}{1.5} & 578.29 & 584.55 & 772.84 & \multirow{3}{*}{866.26} \\
\hline & \multirow[t]{2}{*}{8} & & 560.52 & 567.48 & 859.26 & \\
\hline & & & 606.1 & 613.93 & 966.67 & \\
\hline
\end{tabular}

From Table 3, with the increase in the amount of modified asphalt emulsion, the amount of sticky sand increases, according to the specification [2], the amount of sticky sand should not be less than $450 \mathrm{~g} / \mathrm{m}^{2}$, the law is clearly visible. When the amount of modified asphalt emulsion is more than $8.5 \%$, the amount of sticky sand significantly exceeds regular requirements. The curve of the amount of modified asphalt emulsion is shown in Figure1.

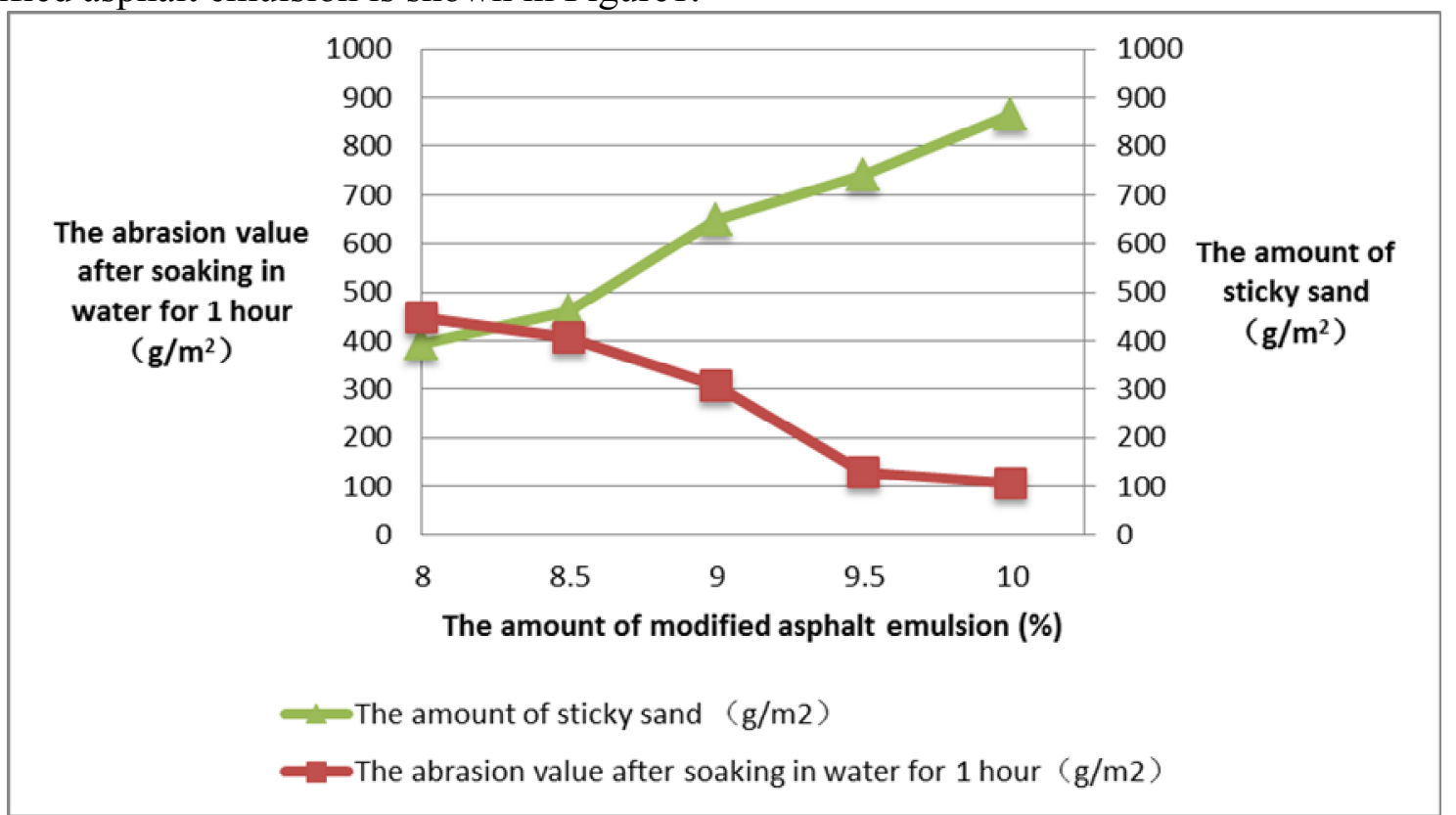

Figure 1 the curve of amount of modified asphalt emulsion

Figure 1 shows that the optimum amount of modified asphalt emulsion is $8.0 \%-8.5 \%$, the paper takes the median valve of $8.3 \%$. After six days of soaking, the wet track abrasion test results are shown in Table 4. 
Table 4 The wet track abrasion test after six days of soaking (Wear area of rubber tube is $0.035 \mathrm{~m}^{2}$ )

\begin{tabular}{ccccccc}
\hline $\begin{array}{c}\text { The amount } \\
\text { of modified } \\
\text { asphalt } \\
\text { emulsion } \\
(\%)\end{array}$ & $\begin{array}{c}\text { The amount } \\
\text { of water }(\%)\end{array}$ & $\begin{array}{c}\text { The amount } \\
\text { of cement } \\
(\%)\end{array}$ & $\mathrm{m}_{\mathrm{a}}$ & $\mathrm{m}_{\mathrm{b}}$ & \multicolumn{3}{c}{$\begin{array}{c}\text { The abrasion } \\
\text { value after } \\
\text { soaking in water } \\
\text { for } 6 \text { days }\left(\mathrm{g} / \mathrm{m}^{2}\right)\end{array}$} & Means \\
\hline 8.3 & 8 & 1.5 & 1070.81 & 1061.51 & 249.14 & 275.71 \\
\hline
\end{tabular}

From Table 4, when the amount of modified asphalt emulsion is $8.3 \%$, all the abrasion values after soaking in water for 6 days can meet the specifications[2] requires (less than 800), indicating that when the amount of modified asphalt emulsion is $8.3 \%$, the mix design can meet the construction requirements.

\section{Conclusions}

Compared with the micro-surfacing mixture without RAP, RAP decreased the amount of modified asphalt emulsion in micro-surfacing mixture, the abrasion value and the amount of sticky sand also can meet regulatory requirements.

Considering the test results and the situation of the RAP after secondary crushing and screening, the optimum amount of modified asphalt emulsion is $8.3 \%$ (The weight ratio of modified asphalt emulsion and aggregate).

Final gradation: Basalt (5-10mm): limestone (0-3 mm): RAP (0-9.5mm): cement (additive): water (additive): modified asphalt emulsion $=10 \%: 60 \%: 30 \%: 1.5 \%: 8 \%: 9.0 \%$ 。

The amount of cement and water can be slightly adjusted according to current temperature and the state of slurry at construction site.

\section{References}

[1] Gang Liu, The mix design and technology researching of micro-surfacing mixture which adding rock asphalt or recycled material, Chang'an University master's thesis, 2014(In Chinese)

[2] Research institute of highway ministry of transport, Technical Guidelines for Micro-surfacing and Slurry seal, China Communications Press,Beijing,2006(In Chinese) 